\title{
IBN TAYMIYYA OG DE GUDDOMMELIGE EGENSKABER
}

\author{
Dorthe Bramsen
}

\section{Indledning}

"Allâhu akbar", Gud er større, er et hyppigt anvendt udsagn inden for den islamiske tradition. Udsagnet anvendes fx i den daglige kalden til bøn, og dets mening er, at uanset hvordan mennesket forestiller sig, at Gud er, er Gud større og mere end det. Bag udsagnet ligger dogmet om Guds absolutte transcendens og væsensforskellighed fra det skabte; et dogme som findes eksplicit udtrykt i Koranen og er almindeligt accepteret inden for den islamisk teologiske tradition. Sure 42.12 lyder: "Intet (eller ingen) er lig Ham", og sure 112.5 lyder: "Og ingen er Hans lige" (A.S. Madsens oversættelse af Koranen).

I Koranen findes imidlertid flere vers, hvori Gud beskrives i forholdsvis konkrete og menneskelige termer. Blandt andet hedder det, at Gud er talende, hørende og seende, har et ansigt og hænder og sidder på tronen i himlen (se fx sure 4.164; 58.1; 96.4; 28.88; 5.64 og 20.5). Disse beskrivelser er af rationalistisk indstillede teologer inden for den islamiske tradition, repræsenteret ved bl.a. mu'taziliter og ash'ariter, blevet tolket allegorisk. Mu'taziliterne $\mathrm{fx}$ anså det guddommelige budskab åbenbaret i form af Koranen for at være rationelt forståeligt for mennesket og afviste, at beskrivelser af Gud, der kolliderer med dogmet om Guds transcendens, kan accepteres i deres ordlyd. Af traditionalistisk indstillede teologer er beskrivelserne derimod blevet taget for pålydende. Hanbaliterne, der står som de mest fremtrædende traditionalistisk indstillede teologer, hævdede fx, at Koranens beskrivelser af Gud er sande uanset deres ordlyd. Således erklærede Ibn Taymiyya (d. 1328), hanbalismens vigtigste repræsentant efter Ahmad ibn Hanbal (d. 855), på baggrund af Koranen, at Gud virkelig er talende og virkelig sidder på tronen i himlen.

Denne artikel vil se nærmere på den traditionalistiske lære om Gud. Hvordan forholdt traditionalisterne sig til dogmet om Guds absolutte transcendens og væsensforskellighed fra det skabte, når en del af deres lære gik på, at Koranens beskrivelser af Gud uanset deres karakter skal tages for pålydende? Fokus vil være på Ibn Taymiyyas lære om Gud og på hans argumentation for den traditionalistiske metodologi. ${ }^{1}$

\footnotetext{
${ }^{1}$ Artiklen er baseret på mit speciale: "Kalâm Allâh, istiwâ' Allâh, nuzûl Allâh. Gudsbeskrivelse og metodologi inden for den hanbalitiske teologiske tradition".
} 


\section{Ibn Hanbal og læren om Koranen}

Den traditionalistiske metodologi bygger i sit grundlag på Ibn Hanbals lære om Koranen. Ibn Hanbal levede i Bagdad under den såkaldte inkvisition, al-mihna (833848), hvor den officielle doktrin om Koranen var, at den er skabt. ${ }^{2}$ Doktrinen var udtryk for en rationalistisk og elitær tilgang til det at være troende, og dens vigtigste eksponenter var mu'taziliterne (Haque 1985, 77-78). Mu'taziliterne, der anså den religiøse sandhed for at være rationel tilgængelig, mente, at de rette doktrinære positioner stemmer overens med den menneskelige fornuft, al- 'aql, og følger den menneskelige logik. Doktrinen om Koranen som skabt baserede de på dette princip og på en tolkning af Guds enhed, tawhîd, der betød, at der er forskel på essentielle og aktive guddommelige egenskaber. Kun de essentielle er uskabte. De aktive - vilje, hørelse, syn og tale - manifesterer sig i tiden og er skabte. ${ }^{3}$ Tolkningen betød, at de konkluderede, at Koranen som Guds Ord åbenbaret til profeten Muhammed i 600-tallet er skabt (Madelung 1974, 504-25).

Denne doktrin modsatte Ibn Hanbal sig imidlertid. For det første anså han det guddommelige budskab for at være hævet over den menneskelige fornuft. Han afviste, at de rette doktrinære positioner nødvendigvis stemmer overens med, hvad mennesket via fornuften kan ræsonnere sig frem til. Den religiøse sandhed fremgår eksklusivt og eksplicit af Koranen og Hadîth. ${ }^{4}$ For det andet mente han, at det af Koranen fremgår, at tale er en uskabt guddommelig egenskab, hvorfor Koranen ikke kan betragtes som skabt (Ibn Hanbal: Radd 'alâ al-jahmîyah wa al-zanâdiqah, oversat i Seale 1964, 116). Den er Guds uskabte Ord og er som sådan ukrænkelig.

Ibn Hanbals lære om Koranen blev den, der blev almindelig accepteret efter 850 . $\mathrm{Mu}$ 'taziliternes rationalistiske doktrin blev afvist, og der opstod en vis form for konsensus om, at Koranens formuleringer er ukrænkelige og skal accepteres i deres ordlyd. Koranen er Guds uskabte Ord, og dens formuleringer må mennesket hverken diskutere, sætte spørgsmålstegn ved eller gå ud over. Det gælder alle formuleringer også dem der omhandler Guds egenskaber. Står der i Koranen, at Gud er hørende, seende og talende, at Han sidder på tronen i himlen og har hænder og et ansigt, ja, så forholder det sig sådan. Står der også, at Gud er ulig alt andet, så forholder det sig også sådan. Hvordan begge dele kan være tilfældet, skal mennesket ikke bekymre sig om. Den guddommelige sandhed er i sin fuldkommenhed ikke tilgængelig for mennesket.

Enigheden var dog ikke fuldstændig. Mu'taziliternes lære om fornuften som primær kilde til viden om Gud og om Koranen som skabt blev afvist, men teologiske skoler, inden for hvilke allegorisk tolkning af Koranen i visse tilfælde er legitim, opstod. Det gjaldt fx den ash'aritiske, der tog navn efter teologen al-Ash'arî (d. 935). Al-Ash'arî og de første generationer af ash'ariter gik ind for, at Koranens ordlyd i alle tilfælde skal

\footnotetext{
${ }^{2}$ For en beskrivelse af inkvisitionen se Hinds 1960.

${ }^{3}$ For en beskrivelse af mu'taziliternes tolkning af tawhîd og af deres doktriner se van Ess 1987 og Gimaret 1960.

${ }^{4}$ Ibn Hanbals lære fremgår blandt andet af hans trosbekendelser. De findes oversat i Watt 1994.
} 
tages for pålydende uden at stille spørgsmål om hvordan, men de senere ash'ariter, der virkede fra sidst i 1000-tallet og frem, gik ind for ta'wîl, dvs. at tolke Koranen allegorisk. ${ }^{5}$ Ash ${ }^{6}$ ariterne blev de senere hanbaliters vigtigste opponenter, herunder Ibn Taymiyyas.

\section{Ibn Taymiyya og beskrivelsen af Gud}

Taqî al-Dîn Ahmad ibn Taymiyya blev født i Harrân i 1263. Som 6-årig kom han til Damaskus med sin familie, og her voksede han op. Han blev uddannet inden for den hanbalitiske tradition, hvis hovedsæde var blevet flyttet fra Bagdad til Damaskus efter mongolernes indtagelse af Bagdad i $1258 .{ }^{6}$ Traditionen havde slået rødder i Damaskus, men den dominerende madhhab var den shâfi'itiske. En del shâfi'iter var traditionalistisk indstillede i teologisk forstand, men flertallet af dem var ash'ariter. ${ }^{7}$

Ibn Taymiyya var udpræget traditionalist og virkede som hanbalitisk retslærd og teolog. Han opponerede kraftigt imod alle de elementer i religionen og samfundet, som han fandt uislamiske, herunder fx de rationalistiske i teologien. Ligesom Ibn Hanbal var Ibn Taymiyya af den overbevisning, at ræsonnementer af rationalistisk karakter ikke hører hjemme i teologiske studier. Koranen og Hadîth udgør de eneste primære kilder til viden om Gud. Dette mente ash'ariterne på sin vis også. De anså ikke som mu'taziliterne fornuften, $a l$ - ' $a q l$, for at være kilde til viden om Gud. De var imidlertid overbeviste om, at det guddommelige budskab i de fleste aspekter er rationelt forståeligt, og at mennesket kan argumentere for den religiøse sandhed ud fra en fornuftsmæssig synsvinkel. Og hvad angår de tilsyneladende antropomorfe beskrivelser af Gud i Koranen, så var de af den holdning, at de skal tolkes allegorisk.

Ibn Taymiyya blev i 1306 dømt for antropomorfisme i Cairo (Ibn Kathîr 1932-39 citeret af Laoust 1942-43, 139; Little 1973, 312f, 320f). Dommen over ham blev fremsagt på baggrund af to af hans trosbekendelser, al- 'Aqîda al-Wâsitiyya og al- 'Aqîda al-Hamawiyya, i hvilke han erklærede, at Gud virkelig er siddende på tronen og virkelig er talende. ${ }^{8}$ Termen, Ibn Taymiyya anvendte for virkelig, er haqîqa - en term der også

\footnotetext{
${ }^{5}$ For en beskrivelse af ash'arismen og dens syn på de guddommelige egenskaber se Anawati 1987, Frank 1987 og Gardet 1960. Se også Makdisi 1962 og 1963.

${ }^{6}$ Korte, men gode beskrivelser af Ibn Taymiyyas liv og levned og af den hanbalitiske tradition findes i Encyclopaedia of Islam og Encyclopedia of Religion.

${ }^{7}$ Den shâfi'itiske madhhab er en retsskole, ikke en teologisk skole. Se Makdisi 1981, 228-38 og 1962, 46-48.

${ }^{8}$ Trosbekendelserne forfattede Ibn Taymiyya i 1298. Førstnævnte findes oversat til både engelsk, tysk og fransk, mens sidstnævnte kun findes på arabisk. Se oversættelserne hos henholdsvis Swartz 1973, Wein 1973, Laoust 1986 og Ibn Taymiyya 1323/1905b. Ifølge Little blev Ibn Taymiyya dømt på grund af sin politiske fremtræden snarere end på grund af sin teologi. Ibn Taymiyya anså således de lærde som gruppe, al- 'ulamâ', for at være korrupte og kritiserede dem i udstrakt grad (Little 1973, 323-26). Little citerer historikeren alBirzâlî angående 'ulamâ's anklager imod Ibn Taymiyya: “... they could find no grounds on which to speak against him because of his abstemiousness, his asceticism, his refusal to compete for office, the greatness of his learning, the merit of his fatwâs and legal responses which revealed his copious knowledge and excellent understanding. Therefore they proceeded to speak against his creed ( 'aqîla) because they preferred the school
} 
kan oversættes med i sandhed eller i bogstaveligste forstand. Det var hans anvendelse af denne term, der gjorde, at hans anklagere anså ham for at sammenligne og sidestille Gud med mennesket. ${ }^{9}$

Hvori Ibn Taymiyyas lære om Gud præcist bestod, og hvordan Ibn Taymiyya argumenterede for den, skal nu belyses.

\section{Balkafiyya-doktrinen}

Ser man på Ibn Taymiyyas lære om Gud, som han fremlægger den i trosbekendelsen alWâsitiyya, står den overordnet som et udtryk for, at beskrivelserne af Gud skal tages for pålydende uden at stille spørgsmål om hvordan (dvs. bi-lâkayf). Ibn Taymiyya kan siges at henholde sig til den såkaldte balkafiyya-doktrin (se Abrahamov 1995). For det første består læren af korancitater, hvis ordlyd Ibn Taymiyya hverken kommenterer eller tolker, og for det andet gør Ibn Taymiyya det eksplicit, at han mener, at Koranens beskrivelser af Gud hverken må negeres, forandres, fortolkes eller føre til en sammenligning af Gud med det skabte. Al-Wâsitiyya lyder:

[This creed] precludes any attempt at altering the original meaning of the sacred texts (tahrîf), and rules out stripping God of his attributes ( $\operatorname{ta}$ ' $t \hat{l} l$ ), or asking questions concerning their modality (takyîf), or attempting to understand them analogically (tamthîl). Indeed, [the Ahl as-Sunna] hold that "there is nothing like unto him; [that] he is the all-hearing and all-seeing one" (42:11). They do not negate what God has attributed to himself, nor do they alter the meaning of his words on these matters, nor subscribe to heretical notions regarding the divine names $(a s m \hat{a})$ and manifestations ( $\hat{a} y \hat{a} t)$. They do not seek to explain his attributes (sifât) or compare them with those of his creatures, for he has no namesake (samîy), no equal (kufu'), no peer (nidd) and, therefore, does not admit of being compared to his creatures. (1323/1905a, oversat i Swartz 1973, 105f)

Balkafiyya-doktrinen ser Ibn Taymiyya som indeholdende princippet om wasat. Wasat betyder midte, og for Ibn Taymiyya er det et formativt teologisk princip, der peger hen på, at de rette doktrinære positioner inkorporerer og forener. De medierer så at sige ekstreme positioner. ${ }^{10}$ Princippet har som grundlag Koranens sure 2.144, og ifølge Ibn

of theologians on the attributes and the Qur'ân to the school of Salaf and believed it to be correct. So they took the response which he had written and made a concerted effort with the qâdîs and fuqahâ', one by one, stirring them up, distorting his words and telling monstrous lies ..." Ibn Taymiyya har skrevet om anklagerne imod sig for antropomorfisme i Munâzara (I-III) og i 3 breve til sine venner og brødre. Se Ibn Taymiyya 1381-86/1961-67a. Munâzara I-II findes oversat i Jackson 1994, 56-85. For en beskrivelse af de 6 dokumenter se Laoust 1986, 20-31. Det skal bemærkes, at såvel venner som fjender har beskrevet Ibn Taymiyya som stædig, egenrådig, opfarende, intolerant, taktløs og udiplomatisk! Se Little 1975, 93-111.

${ }^{9} \mathrm{Se}$ fx anklagernes udtalelser gengivet af Ibn Taymiyya i hans erindringer fra de rådsforsamlinger, der fandt sted i Damaskus i 1306 umiddelbart forud for, at han blev dømt for antropomorfisme i Cairo, Ibn Taymiyya 1381-86/1961-67a oversat i Jackson 1994, 72.

${ }^{10}$ Ibn Taymiyya er i sin forståelse og brug af begrebet wasat influeret af at-Tahâwî (d. 933), som var influeret af Abû Hanîfa (d. 767). Se Wein 1973, 21. For Ibn Taymiyyas forståelse og brug af wasat som teologisk princip se også Swartz 1973, 96 f og Laoust 1939a, 155, 221 og 248. 
Taymiyya kommer det bl.a. til udtryk i måden, Gud er beskrevet på, i Koranen. ${ }^{11}$ Som han skriver: "In the description that he gave of himself, the Most High employed statements of negation (nafy) as well as statements of affirmation (ithbât)" (1323/1905a, oversat i Swartz 1973, 106). ${ }^{12}$

Balkafiyya-doktrinen indeholder ifølge Ibn Taymiyya princippet om wasat, idet den på den ene side afviser, at mennesket må stille spørgsmål vedrørende de guddommelige egenskabers modalitet, kayfiyya, og på den anden side bekræfter, at de guddommelige egenskaber skal accepteres som sande i deres ordlyd. Den medierer så at sige ta 'tîl, det at benægte eksistensen af de guddommelige egenskaber, og tamthîl, det at sammenligne de guddommelige egenskaber med menneskelige egenskaber (1323/1905a, oversat i Swartz 1973, 115). Som sådan mener Ibn Taymiyya, at den - og dermed også hans lære om Gud - stemmer direkte overens med Guds vilje og lov åbenbaret i form af Koranen.

\section{Termen haqîqa}

Ibn Taymiyya nøjedes imidlertid ikke med i sin beskrivelse af Gud at citere Koranen. Som nævnt anvendte han i forbindelse med sin lære om Gud termen haqîqa (virkelig, i sandhed). I al-Wâsitiyya skriver han fx om Koranen: "Gud har virkelig talt dens ord (Allâhu takallama bi-hi haqîqatan) ... Den er i sandhed Guds Ord (Huwa kalâmu Allâhi haqîqatan )..." (1323/1905a, gengivet af Laoust 1986, 16). ${ }^{13} \mathrm{Og}$ samme sted skriver han om Gud som ophøjet, befindende sig på tronen, og som nær mennesket: "Og alt det, som Gud har ladet os vide - at Han er over tronen, og at Han er med os - er virkeligt sandt (haqqun 'alâ haqîqati-hi) ..." (s. 15).

Ibn Taymiyyas anvendelse af termen haqîqa betød som allerede nævnt, at han blev anklaget og dømt for sin lære om Gud. Hvordan han forsvarede sig imod anklagerne for antropomorfisme, og hvori hans argumentation for det at anvende termen haqîqa bestod, skal nu skitseres.

\section{Traditionalistiske argumenter}

Ibn Taymiyyas lære om de guddommelige egenskaber og hans argumentation for det at anvende termen haqîqa fremstår først og fremmest traditionalistisk. Dvs. den består i overvejende grad af henvisninger til de første generationer af muslimer kaldet salaf, til princippet om ijmâ', konsensus blandt de lærde, og til Koranen.

Hvad angår henvisninger til salaf, så findes de fx i trosbekendelsen al-Hamawiyya. Heri gør Ibn Taymiyya det klart, at salaf, hvis lære han mener, det er pligtigt for enhver

\footnotetext{
${ }^{11}$ Sure 2.144 lyder: "Og således har vi gjort jer til et samfund i midten (umma wasat), at I må være vogtere over menneskene, og sendebudet må være vogter over jer”.

${ }^{12}$ Som dokumentation herfor citerer Ibn Taymiyya bl.a. koranvers, der gør det klart, at Gud er væsensforskellig fra mennesket (1323/1905a, oversat af Swartz 1973, 106f og 110), og koranvers, hvori det stadfæstes, at Gud kan se, høre og tale, har ansigt og hænder og befinder sig på tronen i himlene (s. 119-21).

${ }^{13}$ Laoust bringer foruden en fransk oversættelse af al-Wâsitiyya den arabiske udgave. Det er den, jeg her har oversat og refererer til.
} 
muslim at følge, accepterede de beskrivelser, der er af Gud i Koranen og i Hadîth, i deres ordlyd, og bekræftede dem, som de står nævnt. ${ }^{14}$ Angående de vers, hvori der i Koranen står, at Gud befinder sig på tronen i himlen, skriver han: “.... at Gud sidder på tronen ... var velkendt tale i efterfølgernes tid ...” (1323/1905b, 431). Og han skriver: “... den, der sætter sig ind i salafs tale, ... han ved med sikkerhed, at salaf udtalte sig klart om, at Gud i sandhed er på tronen (Allâhu fawqa al- 'arshi haqîqatan)" (s. 461).

Han gør det også klart, at salaf, de fromme forfædre, omend de bekræftede sandhedsværdien af Koranens beskrivelser af Gud, tog eksplicit afstand fra tashbîh, det at sammenligne Guds egenskaber med menneskets. Deres position kan derfor ikke karakteriseres som antropomorfistisk. Ibn Taymiyya skriver kort og godt: “... de benægtede tashbîh, og de følte klar modvilje mod dem, som sammenlignede Gud med det skabte, ligesom de følte modvilje mod dem, som afviste og benægtede de guddommelige egenskaber" (s. 462).

Hvad angår henvisninger til princippet om ijmấ, så kommer Ibn Taymiyya fx med dem under de rådsforsamlinger, der fandt sted i Damaskus i 1306 forud for, at han blev dømt for antropomorfisme i Cairo. Han erklærer bl.a.: "There is no doubt that God is literally alive (hayyun haqîqatan), literally knows, literally hears, and literally sees. On this there is consensus among Ahl al-Sunnah and those who accept the divine attributes among all the parties" (1381-86/1961-67a, oversat i Jackson 1994, 80).

Og hvad angår henvisninger til Koranen, så argumenterer Ibn Taymiyya fx som nævnt i trosbekendelsen al-Wâsitiyya for, at hans lære om de guddommelige egenskaber er et udtryk for, at han henholder sig til balkafiyya-doktrinen, og at denne doktrin er baseret på Koranen. Han henviser dog også mere eksplicit til Koranen i sin argumentation for, at det at tilskrive Gud egenskaber, som også mennesket kan besidde, og bekræfte dem som sande, ikke er et udtryk for antropomorfisme. I skriftet Su'al fi hadîth al-nuzûl wa-jawâbuhu aw sharh hadîth al-nuzûl argumenterer han $\mathrm{fx}$ for, at når mennesket bekræfter, at et givent udsagn om Gud er sandt, så bekræfter det kun, at udsagnets ordlyd som sådan er sand. Det bekræfter ikke, hvordan udsagnet er sandt. Argumentationen baserer han på sure 3.7, som han mener gør det klart, at det guddommelige budskab har to aspekter: ét aspekt der går på budskabets ydre betydning, og ét aspekt, der går på budskabets indre mening. Kun det aspekt, der går på budskabets ydre betydning er tilgængeligt for mennesket. Det andet, som går på budskabets indre mening og fx vedrører de guddommelige egenskabers modalitet, kayfiyya, er forbeholdt Gud. Argumentationen skal ses i lyset af, at sure 3.7, som omhandler Koranens klare vers (âyât muhkamât) og uklare vers (âyât mutashâbihât), er tvetydig. Den lyder med henvisning til de uklare vers: "wa-mâ ya"lamu ta'wîlahu illâ Allâhu wa l-râsikhûna fî 1-'ilmi yaqûlûna: âmannâ bi-hi”" (Og ingen kender deres tolkning foruden Gud og de der er fast grundede i viden (de) bekræfter: Vi tror på dem) (egen oversættelse). Tvetydigheden består i, at suren både kan siges at bestå af én sætning, hvor al-râsikhûna, de der er fast grundede i viden, er subjekt sammen med Allâh, og af to sætninger, hvor

${ }^{14}$ Om salafs betydning ifølge Ibn Taymiyya se Swartz 1973, 129 og Laoust 1939b, 111. 
konstruktionen wa l-râsikhûna indleder den sidste. Består den af én sætning, betyder den, at såvel Gud som de, der er fast grundede i viden, kan forstå indholdet af de uklare vers, og består den af to sætninger, betyder den, at kun Gud kender den rette tolkning af de uklare vers, mens de, der er fast grundede i viden, bekræfter, at de tror på dem. Ibn Taymiyyas pointe og argument er, at begge betydninger af suren er sande; de refererer blot til hver deres aspekt af det guddommelige budskab. ${ }^{15}$ Førstnævnte betydning refererer til det aspekt af budskabet, der går på budskabets ydre betydning, og anden nævnte betydning refererer til det aspekt, der går på budskabets indre mening. På baggrund heraf konkluderer han, at når mennesket bekræfter et givet udsagns sandhedsværdi, så bekræfter det kun den sandhedsværdi, der går på udsagnets ydre betydning, eftersom den er den eneste, der er tilgængelig for mennesket. Den anden, dvs. den indre, der går på budskabets modalitet, er forbeholdt Gud (Ibn Taymiyya 1993, refereret $\mathrm{i}$ Abrahamov 1995, 374).

\section{Lingvistiske argumenter}

Ibn Taymiyya argumenterer dog også lingvistisk for sin lære om Gud og for sin anvendelse af termen haqîqa i forbindelse hermed. Blandt andet i al-'Aqîda al-Wâsitiyya (se fx Ibn Taymiyya 1232/1905a, oversat af Swartz 1973, 117) og al'Aqîda al-Hamawiyya. I sidstnævnte stadfæster han, at anvender man termen haqîqa om et udsagn relateret til Gud, betyder det ikke - i hvert fald ikke nødvendigvis - at man opfatter udsagnet som sandt set ud fra en leksikalsk og fysisk betragtning. At bekræfte de guddommelige egenskabers eksistens som sand eller virkelig, selv om egenskaberne også kan tilskrives mennesket, er derfor ikke nødvendigvis et udtryk for antropomorfisme. Bekræfter man fx, at Gud er i himlen, så betyder det ikke - om end præpositionen $f i$, i, der er indeholdt i udsagnet, normalt refererer til noget rumligt - at man udtaler sig om, hvor Gud rent fysisk befinder sig. Han skriver: "Den, som bilder sig ind, at det at Gud er i himlen betyder, at himlen omgiver Ham [Gud] og rummer [Ham], han er en løgner ... For med himlen menes der kun højhed, og meningen [med udtrykket] er, at Gud er i det høje, ikke i det lave" (1323/1905b, 458f).

Som bevis for, at man kan betragte udsagnet "Gud er i himlen" som sandt, uden at man af den grund behøver at tillægge det den vanlige leksikale og fysiske betydning, nævner han, at præpositionen $f i$, som altså står som en del af udsagnet, flere steder i Koranen anvendes i betydningen 'alâ, på. Det gør den fx i sure 20.72, hvori der står: “... og jeg vil korsfæste jer på palmestammer (fi judhû 'i al-nakhli)”, og det gør den i sure 16.37, hvori der står: "Drag da omkring på jorden (fî l-'ardi)" (A.S. Madsens oversættelser). Og som han siger om det, der står i Koranen: “... det er arabisk tale i sandhed (huwa kalâm 'arabî haqîqatan)” (1323/1905b, 459).

\footnotetext{
${ }^{15}$ At Ibn Taymiyya mener, at begge betydninger af suren er sande, afspejler, at han henholder sig til princippet om wasat. De fleste andre koranfortolkere så de to betydninger af sure 3.7 som modstridende og holdt på, at kun én af betydningerne er sand. Zamakhsharî (d. 1144) holdt fx på, at førstnævnte betydning af suren er sand, mens at-Tabarî (d. 923) og også Ibn Qudâma (d. 1223) holdt på, at sidstnævnte betydning af suren er sand. Se Peters 1994, 192-4 og Rippin \& Knappert 1986, 42-6.
} 


\section{Rationalistisk-filosofiske argumenter}

Endelig argumenterer Ibn Taymiyya også sprogfilosofisk for, at det at bekræfte de guddommelige egenskaber, som de står nævnt i Koranen og Hadîth, som sande i deres ordlyd, ikke er et udtryk for antropomorfisme. I Kitab al-'Iman som et eksempel på Book of Faith, fastslår han, at ingen udtryk i Koranen skal forstås allegorisk eller figurativt. Termen, han anvender her, er majâz. Alle udtryk, inklusive dem der består i tilsyneladende antropomorfe beskrivelser af Gud, skal accepteres i deres ordlyd haqîqatan (1999, 118). Det at skelne imellem figurativ og litterær betydning af et ord, dvs. imellem majâz og haqîqa, er et udtryk for bid'a, illegitim fornyelse. Som Ibn Taymiyya skriver: “... the division of languages into literal and figurative usages is a later innovation that was never advocated by the pious ancestors" (s. 125).

Hævdelsen af, at alle ord skal accepteres som sande i deres ordlyd, baserer Ibn Taymiyya overordnet på en tese om, at sproget er givet af Gud til mennesket. Det er ikke en menneskelig opfindelse, og mennesket kan ikke uden videre siges at kende til ordenes egentlige og bagvedliggende mening (s. 102-4, 106f). ${ }^{16}$ Underordnet baserer han dette på et argument for, at skal et udtryk kunne forstås allegorisk, skal det også kunne forstås på en anden og mere oprindelig og absolut måde (s. 111). Og sidstnævnte, påpeger Ibn Taymiyya, er ikke tilfældet. Han skriver:

... there is no noun, verb, or particle in any complete utterance that is used without some restrictions that preclude its being understood in an absolute sense. ... the single word has always been used within a conditioned context, namely, the complete sentence. (s. 112)

Påpegningen af, at betydningen af ethvert udtryk specificeres og kvalificeres ud fra den givne sproglige kontekst, tjener som argument for, at det at tilskrive Gud egenskaber, som også mennesket kan besidde, ikke medfører antropomorfisme. For som Ibn Taymiyya skriver om følgende egenskaber, der i Koranen tilskrives Gud:

... the realities referred to by terms such as 'will', 'knowledge', 'ability', or 'general, absolute existence' do not exist in isolation in the mind. For such entities have no independent referents; the word 'will', for example, is never used without being associated in some way with a being that does the willing, just as the word 'knowledge' is used only in association with some being who does the knowing, and the word 'ability' is found only in association with some entity which is 'able'. (s. 120)

Egenskaberne er altså ikke absolutte størrelser. Hvori de består, og hvilken betydning de termer, der refererer til dem, har, er betinget af den kontekst, de indgår i. Ser man fx på betydningen af termen istiwâ', der betyder sidden, og den virkelighed, der ligger bag, skriver Ibn Taymiyya i al- 'Aqîda al-Hamawiyya, står det klart, at den er en anden, når den gælder Gud, end når den gælder mennesket. Gælder den Gud, specificeres den altid med tronen, hvorved det gøres eksplicit, at istiwâ' Allâh er forskellig fra menneskets

${ }^{16}$ Denne tese såvel som dens anti-tese tages op og diskuteres af Abu Zaid 2000, 194f. 
sidden $(1323 / 1905 b, 458) .{ }^{17}$ Som Ibn Taymiyya også udtrykker det: "God is seated on his throne in a manner appropriate to his glory and unique to him" (1323/1905b citeret $\mathrm{i}$ Swartz 1973, 116, note 42). ${ }^{18}$

Ibn Taymiyya argumenterer også erkendelsesteoretisk for sin lære om Gud, fx under rådsforsamlingerne i Damaskus. Presset af anklagerne, der mente, at anvender man termer i forbindelse med Gud - termer som også kan anvendes i forbindelse med mennesket - og bekræfter dem som sande, så kan det ikke være udtryk for andet, end at man sidestiller og sammenligner Gud med mennesket, siger Ibn Taymiyya, idet han eksemplificerer ved hjælp af termen 'eksistens':

Whether the term 'existence' is applied to the uncreated and the created denotatively ( $b i$ al-ishtirâk al-lafzî), or connotatively (bi-al-tawâtu'), which entails the intermingling of both the expression and its meaning, or ambiguously (bi-al-tashkik), which is a type of connotative usage - on every usage, God literally exists; and created entities literally exist as well. To apply a term in its literal sense to both the Creator and the created entails no danger. (1381-86/1961-67a, oversat i Jackson 1994, 80)

Selv anser han termerne, der anvendes i forbindelse med Gud, for at være konnotative, og det er i det lys, hans videre argumentation skal ses. I sine erindringer fra rådsforsamlingerne skriver han: "Indeed, the truth of the matter is that these names [the names of God] are in fact used connotatively (bi-al-tawâtu')" (Jackson 1994, 83). Hvad han mener med det, fremgår foruden af ovenstående, hvor han forklarer, at det "entails the intermingling of both the expression and its meaning", af al- 'Aqîda al-Hamawiyya. I den skriver han om denotative termer, al-'asmâ' al-mushtaraka, at de i modsætning til konnotative termer, al-asmâ ' al-mutawâti' a, kun har fælles andel i udtrykket, dvs. de er homonymer. Det betyder, at han mener, at konnotative termer foruden udtrykket har noget indholdsmæssigt til fælles (1323/1905b, 458). ${ }^{19}$

Argumentationen for at termer, der kan anvendes om både Gud og mennesker, er sande i deres ordlyd, når de gælder Gud, ikke medfører antropomorfisme, baserer Ibn Taymiyya på det faktum, at det for alle elementer i den fysiske verden gælder, at selvom de betegnes med samme term og deler visse fællestræk, så er de individuelt forskel-

\footnotetext{
${ }^{17}$ Menneskets sidden har således ikke noget med den himmelske trone at gøre.

${ }^{18}$ I Kitab al-'Iman gør han endvidere opmærksom på, at termerne hånd og fod, som også tilskrives Gud i Koranen og Hadîth, er specificerede i kraft af, at de indgår i possesive konstruktioner (1999, 110).

${ }^{19}$ For betydningen af det at anvende en term konnotativt se også Jackson 1994, 54, og Abrahamov 1995 , 372f. I Politikens Filosofileksikon står der, at en terms konnotation er termens betydning eller abstrakte definition, dvs. bestemmelsen af betingelserne for, at termen er sand om en given genstand. Og som et eksempel gives der, at termen ungkarl har alle ugifte mandspersoner som konnotation. Som denotation har termen samtlige ungkarle. Denne anvendelse af konnotation er imidlertid ikke identisk med Ibn Taymiyyas. Ibn Taymiyya henholdt sig således til den referentielle betydningsterori, ifølge hvilken ethvert ord refererer til noget - hvis ikke noget konkret, så noget abstrakt. Denne teori blev forkastet i løbet af 1900-tallet, og moderne sprogfilosoffer forstår betydningen af en term som noget, der har at gøre med betingelserne for, at termen er sand om en given genstand. For en introduktion til sprogfilosofien se fx Collin og Guldmann 1998.
} 
lige. ${ }^{20}$ Det fremgår af hans erindringer fra rådsforsamlingerne (Ibn Taymiyya 138186/1961-67a, oversat i Jackson 1994, 83. Se også Hallaq 1991, 51f) og af en bog rettet imod folkelig religiøs praksis. I sidstnævnte skriver han, idet han atter eksemplificerer ved hjælp af termen 'eksistens':

Existence is shared by that which is self-existent and that which is existent-throughanother, or that which is necessary-by-itself and that which is contingent-by-itself, just as animals share in the term 'animal', and human beings share in that which is designated by the term 'man', despite the self-evident knowledge that the existential identity of this man is not the existential identity of this horse, indeed not even the existential identity of this animal or his animality and humanity is the existential identity of that animal or his animality or humanity. There is, however, between them a certain similarity wherein they resemble, which is sometimes called an absolute universal and a common factor, etc. But this does not exist in the external reality outside the mind as an absolute and general universal. Indeed in the external reality nothing exists except particular existents. Every existent, therefore, has his particular mode of being which is not shared by anything else. Indeed between any two external existents there is nothing which they 'share' in common; they only resemble each other. This has something, for instance, corresponding to that, just as this itself corresponds to that, while each of the two is distinct in its being and its attributes from everything else. (1950, oversat i Memon 1976, 329)

Teksten afsluttes med bemærkningen: "Such being the case, how about God the Creator and the Exalted!" (s. 329). ${ }^{21}$ Forholdet skal ses i lyset af, at Ibn Taymiyya var empiriker og mente, at viden om skjulte ting kan mennesket kun få gennem analogislutninger, eftersom viden - foruden den der er baseret på Koranen og Hadîth - kun kan baseres på erfaringen i form af sanseoplevelser. ${ }^{22}$

\section{Mental association}

Med hensyn til Ibn Taymiyyas teori om, at de termer, der i Koranen og Hadîth appliceres på Gud, er termer, der appliceres konnotativt, skal det bemærkes, at den åbner for, at mennesket - ganske vist kun på et abstrakt plan - kan foretage analogislutninger; dvs. slutninger der går fra, hvordan mennesket er, til hvordan Gud er. For om elementer, der refereres konnotativt til, gælder det, at det, de har til fælles foruden betegnelsen, har indholdsmæssig karakter. Ibn Taymiyyas måde at forholde sig til forskellige åbenbarede og overleverede beskrivelser af Gud på, kan da også netop siges at være et udtryk for, at han er af den opfattelse, at mennesket ikke kan forholde sig til

\footnotetext{
${ }^{20}$ Forholdet peger på sin vis hen på det allerede nævnte, nemlig det at ingen ord - og da slet ikke ord der peger hen på egenskaber - har en absolut betydning. De indgår altid, som Ibn Taymiyya formulerer det, i en specifik sproglig kontekst $(1999,109,112)$. Argumentationenen, jeg her bringer, foregår dog på et andet analytisk niveau.

${ }^{21}$ For andre eksempler se Hallaq 1991, 53f og Ibn Taymiyya 1999, $392 \mathrm{f}$.

${ }^{22}$ For en beskrivelse af Ibn Taymiyya som empiriker se Hallaq 1991, 53 og Abrahamov 1995, 374.
} 
en aldeles transcendent og ukendt Gud. Han mener, at mennesket - i hvert fald i sit indre - har behov for at kunne danne sig et billede af, hvordan Gud er. I et skrift rettet imod spekulativ sufisme påpeger han, at Gud for at kunne tjenes, nødvendigvis må besidde aktive og positive egenskaber (1949, refereret i Memon 1976, 33). Og i et andet skrift påpeger han, at menneskets tro på og lyst til at tjene Gud først og fremmest udspringer af viden om og kendskab til Gud (1993, refereret i Abrahamov 1995, 375). Endvidere fremhæver han i al- 'Aqîda al-Wâsitiyya, at Gud på trods af sin transcendens er nær mennesket, dvs. er inden for menneskets rækkevidde. Han citerer bl.a. sure 57.5: "Han er med jer, hvor I end er, og Allah ser (alt), hvad I gør" (A.S. Madsens oversættelse), og skriver: "It is essential to believe that God is near and responds in the affirmative to those who call upon him as the Quran indicates: 'When my servants inquire concerning me - I am near to answer the call of the caller, when he calls to me' (2:186)" (1323/1905a, oversat i Swartz 1973, 117). Fremhævelsen står godt nok som et konkret vidnesbyrd om, at Ibn Taymiyya henholder sig til princippet om wasat. Den peger dog også hen på, at Ibn Taymiyya vægter det personlige gudsforhold højt. ${ }^{23}$

Der er i forbindelse med Ibn Taymiyyas accept af, hvad man kan kalde mental association (Jackson 1994, 55f), vigtigt at påpege, at den ikke betyder, at Ibn Taymiyya mener, at det er mennesket tilladt at foretage analogislutninger - slutninger der går fra, hvordan mennesket er, til hvordan Gud er - på det praktiske og konkrete plan. Ibn Taymiyya afviser eksplicit, at der i den virkelige verden findes ligheder mellem Gud og mennesket, ligesom han afviser, at mennesket kan erhverve sig egentlig og positiv viden om, hvordan Gud er. I al- 'Aqîda al-Hamawiyya skriver han fx: "The proof of the intellect's inability to know the true meaning of God's attribute (tahqî sifatihi) is its inability to know the attribute of the smallest of God's created beings" (1323/1905b, citeret i Abrahamov 1995, 376). Og under rådsforsamlingerne, hvor han beskyldes for tashbîh- og tajsîm-antropomorfisme, erklærer han med henvisning til al-'Aqîda alWâsitiyya og den udlægning af sure 3.7, som er gennemgået:

I disallowed takyîf, following the example of the Ancestors, while it is also forbidden by scripture; for subjecting the verses on God's attributes to allegorical interpretation $\left(t a^{\prime} w \hat{\imath} l\right)$ entails allegorically interpreting the One described, as well as His attributes. These are matters the inner meaning ( $t a^{\prime}$ 'will) of which is the preserve of God alone, as I have established in a separate precept on 'inner meaning' ( $t a$ 'wîl) and 'meaning' ( $m a$ ' $n \hat{a}$ ), and the difference between our knowing the meaning of a statement and our knowing its inner meaning. Similarly, tamthîl-anthropomorphism has been disallowed by scripture, as well as age-old consensus, not to mention the rational proofs of its incorrectness along with the incorrectness of takyîf, since the inner essence of the Giver of Form is not known to man (1381-86/1961-67a, oversat i Jackson 1994, 62).

\footnotetext{
${ }^{23}$ At Ibn Taymiyya vægter det personlige gudsforhold højt fremgår bl.a. af Kitâb al-'Îmân og Kalâm 'alâ da 'wat Dhî 'l-Nûn. I Kitâb al-' Ŷmân gør Ibn Taymiyya det klart, at tro er noget individuelt (jf. Swartz 1973, 123, note 62), og i Kalâm 'alâ da'wat Dhî 'l-Nûn gør han det eksplicit, at hvis mennesket vil opnå fuldkommenhed, må det angre sine synder for Gud og søge tilgivelse for dem (1381-86/1961-67b, citeret i Ahmed 1998, 95). At angre og søge tilgivelse for noget forudsætter et personligt forhold.
} 
Endvidere gør han det i al- 'Aqîda al-Wâsitiyya klart, at det absolut vigtigste budskab i Koranen er, at Gud er den eneste gud, at Gud er én, og at Han er væsensforskellig fra alt andet. Han citerer således sure 112.1-4 og sure 2.255 efter at have erklæret, at disse to koranvers indeholder "the essence of what God has revealed concerning himself" (1323/1905a, oversat i Swartz 1973, 106f).

\section{Konklusion}

Den traditionalistiske lære om Gud indeholdt, som det er fremgået, et princip om, at Gud skal beskrives, som Han står beskrevet i Koranen uanset Koranens ordlyd. Den betød, at traditionalisterne repræsenteret ved hanbaliterne bl.a. beskrev Gud som talende og som siddende på tronen i himlen. Princippet var baseret på doktrinen om Koranen som Guds uskabte og derfor ukrænkelige Ord, og på metodologien om, at Koranen sammen med Hadîth udgør eneste primære kilde til viden om Gud. Mennesket kan ikke via fornuften ræsonnere sig frem til, hvordan Gud er.

Hanbaliternes lære betød imidlertid ikke, at de ikke henholdt sig til dogmet om Guds transcendens og væsensforskellighed fra det skabte. Ser man fx på Ibn Taymiyyas lære om Gud, så fremstår den som et avanceret traditionalistisk, sprogvidenskabeligt og erkendelsesteoretisk forsvar for Guds uerkendelighed. Ibn Taymiyyas lære gør det klart, at han i sin teologi søgte at forene princippet om, at beskrivelserne af Gud i Koranen er sande og skal accepteres i deres ordlyd, med dogmet om Guds transcendens og væsensforskellighed fra det skabte. Hans lære peger hen på, at han henholdt sig til princippet om wasat, dvs. princippet om både og. ${ }^{24}$

Ser man på måden, Ibn Taymiyya beskrev Gud på, så vidner den om, at Ibn Taymiyya henholdt sig til balkafiyya-doktrinen. Doktrinen indeholder såvel et element af bekræftelse som et element af benægtelse. I doktrinen bekræftes det, at Gud er, som der står Han er i Koranen, og det benægtes eller afvises, at mennesket må stille spørgsmål vedrørende de guddommelige egenskabers modalitet. Måden er et udtryk for, at Ibn Taymiyya samtidig med, at han tog Koranens beskrivelser af Gud for pålydende, henholdt sig til dogmet om Guds transcendens og væsensforskellighed fra det skabte.

Og ser man på Ibn Taymiyyas forsvar for sandhedsværdien af de termer, der i Koranen er brugt om Gud, vidner det om, at Ibn Taymiyya så sproget som gudskabt. Han mente, at mennesket uden fare for at gøre sig skyldig i antropomorfisme kan bekræfte, at Koranens termer om Gud er sande i deres ordlyd. Kun Gud kender termernes egentlige mening. Det vidner også om, at Ibn Taymiyya opfattede de termer, Gud i Koranen er beskrevet med, for at være konnotative. Det betød ifølge ham, at det, de refererer til, er abstrakte universalia, og det at de kan anvendes om både Gud og menneske, ikke indikerer, at Gud og menneske er ens. Det indikerer kun, at der på det abstrakte plan - men kun det abstrakte - er visse fællestræk mellem Gud og menneske. Sidstnævnte var vigtigt for Ibn Taymiyya. Ikke kun fordi han vægtede Guds transcen-

\footnotetext{
${ }^{24}$ Dette har man ikke erkendt i den ældre orientalistiske forskning. I den så man først og fremmest Ibn Taymiyyas lære som anti-intellektualistisk og usammenhængende. For en oversigt se Makdisi 1981.
} 
dens, men fordi han samtidig vægtede det personlige gudsforhold. Han mente ikke, at mennesket kan tro på og tjene en aldeles transcendent gud; en gud der ikke på en eller anden måde kan konceptualiseres. ${ }^{25}$ Gud er ifølge Ibn Taymiyya transcendent, men Han er også beskrivelig. Han er både og.

\section{Litteratur}

ABRAHAMOV, BINYAMIN

1995 "The bi-lâ kayfa Doctrine and its Foundations in Islamic Theology", Arabica, vol. 42, Leiden, 365-79.

ABU ZAID, NASR HAMID

2000 “Divine Attributes in the Qur'an: Some Poetic Aspects", John Cooper, Ronald Nettler \& Mahmoud, Mohamed, eds., Islam and Modernity - Muslim Intellectuals Respond, London og New York, 190-211.

AHMED, SHAHAB

1998 "Ibn Taymiyya and the Satanic Verses", Studia Islamica, vol. 87, Paris, 67-124.

AnAwATI, Georges C.

1987 “Attributes of God", Eliade, ed., Encyclopedia of Religion, vol. 1, New York, 512-19. "Kalâm”, Eliade, ed., Encyclopedia of Religion, vol. 8, New York, 231-42.

Collin, Finn \& FinN Guldmann, eds.

1998 Sprogfilosofi - en introduktion, København.

ESS, JOSEF VAN

1987 “Mu'tazilah”, Eliade, ed., Encyclopedia of Religion, vol. 10, New York, 220-29.

FRANK, R.M.

1987 “Al-Ash'arî” og “Ash'arîya”, Eliade, ed., Encyclopedia of Religion, vol. 1, New York, 445-55.

GARDET, L.

1960 “"Ilm al-kalâm”, Encyclopaedia of Islam, vol. 3, second edition, London, 1141-50.

GIMARET

1960 "Mu'tazila", Encyclopaedia of Islam, vol. 7, second edition, London, 783-93.

HALlaQ, WAEL B.

1991 "Ibn Taymiyya on the Existence of God", Acta Orientalia, vol. 52, København, 49-69.

HAQUe, ZiAUL

1985 “Ahmad ibn Hanbal: the Saint-Scholar of Baghdad”, Hamdard Islamicus, vol. 8/3, Nizamabad, Pakistan, 67-90.

HINDS, M.

1960 "Mihna", Encyclopaedia of Islam, vol. 7, second edition, London, 2-6.

IBN KATHîR

1932-39

Al-Bidâya wa-al-nihâya, 14 vol, Cairo.

\footnotetext{
${ }^{25}$ Ibn Taymiyya var sufi og medlem af den såkaldte Qadariyya-orden (Makdisi 1981, 249).
} 
IBN TAYMIYYA

$1323 / 1905 a$

“Al-'aqîda al-wâsitiyya”, Majmû 'at al-Rasâ'il al-Kubrâ, vol. 1, Cairo, 387-406. $1323 / 1905 b$

"Al-'aqîda al-hamawiyya al-kubrâ", Majmû' 'at al-Rasâ'il al-Kubrâ, vol. 1, Cairo, 414-69.

1949 Kitâb ar-Radd 'alâ al-mantiqîyîn, Bombay.

1950 Kitâb iqtidâ' as-sirât al-mustaqîm mukhâlafat ashâb al-jahîm, Cairo.

$1381-86 / 1961-67 a$

"Munâzara", Majmû' fatâwâ shaykh al-islâm Ahmad b. Taymiyya, vol. 3, Riyâd, $160-201$.

1381-86/1961-67b

"Kalâm 'alâ da'wat Dhî 'l-Nûn”, Majmû' fatâwâ shaykh al-islâm Ahmad b. Taymiyya, vol. 10, Riyâd, 237-337.

1993 Su'âl fì hadîth al-nuzûl wa-jawâbuhu aw sharh hadîth al-nuzûl, Riyâd.

1999 Kitab al-Iman, Book of Faith, Bloomington, Indiana.

JACKSON, SHERMAN A.

1994 "Ibn Taymiyyah on Trial in Damascus", Journal of Semitic Studies, vol. 39/1, Oxford, 41-85.

LAOUST, HENRI

1939a Essai sur le doctrines sociales et politiques de Taki-d-Dîn Ahmad b. Taimîya, Cairo.

1939b Contribution a une étude de la méthodologie canonique de Taki-d-dîn Ahmad b. Taimîya, Cairo.

$1942-43$

"La Biographie d'Ibn Taymiyya d'après Ibn Kathîr", Bulletin d'Études Orientales, vol. IX, Damaskus, 115-62.

1960 "Ibn Taymiyya", Encyclopaedia of Islam, vol. 3, second edition, London, 951-55. "Hanâbila", Encyclopaedia of Islam, vol. 3, second edition, London, 158-62.

1986 La profession de foi d'Ibn Taymiyya, Paris.

LiTTLE, D.P.

1973 "The Historical and Historiographical Significance of the Detention of Ibn Taymiyya" $i$ International Journal of Middle East Studies, vol. 4, Cambridge, 311-27.

1975 “Did Ibn Taymiyya have a screw loose?", Studia Islamica, vol. 41, Paris, 93-111.

MADELUNG, WILFERD

1974 "The Origins of the Controversy concerning the Creation of the Koran", J.M. Barral, ed., Orientalia Hispanica, vol 1, 504-25.

MAKDISI, GEORGE

1962 “Ash'arî and the Ash'arites in Islamic religious History”, Studia Islamica, vol. 17, Paris, 37-80.

1963 “Ash'arî and the Ash'arites in Islamic religious History”, Studia Islamica, vol. 18, Paris, 19-39.

1981 "Hanbalite Islam", Merlin L. Swartz, ed., Studies on Islam, Oxford, 216-74.

1987 “Ibn Taymîyah”, Eliade, ed., Encyclopedia of Religion, vol. 6, New York, 571-74. “Hanâbilah”, Eliade, ed., Encyclopedia of Religion, vol. 6, New York, 178-88.

Memon, Muhammad Umar

1976 Ibn Taimîya's Struggle against Popular Religion, Haag.

PETERS, F.E.

1994 A Reader on Classical Islam, Princeton. 


\title{
Ibn Taymiyya og de guddommelige egenskaber
}

RIPPIN, A. \& J. KNAPPERT, eds.

1986 Textual Sources for the Study of Islam, Manchester.

SEALE, Morris S.

1964 Muslim Theology, London.

SWARTZ, MERLIN

1973 "A seventh-century (A.H.) Sunnî creed: The 'Aqîda Wâsitîya of Ibn Taymîya", Humaniora Islamica, vol. 1, Haag, 91-131.

WATT, W. MONTGOMERY

1994 Islamic Creeds, Edinburgh.

Wein, Clemens

1973 Die Islamische Glaubenslehre ('Aqîda) des Ibn Taimîya, Bonn.

\begin{abstract}
Summary
According to Islamic theology God is transcendent and different to anything created. There are many verses in the Qur'ân, however, which describe God in almost anthropomorphic terms. He is described as talking and as sitting on the heavenly throne. Throughout history Muslim traditionalists have claimed that these verses must not be interpreted. They are to be accepted as true in their own sense. If the Qur'ân describes God as talking and as sitting on the heavenly throne, then He is actually talking and sitting on the heavenly throne.

This article examines the teaching of one of the most celebrated traditionalists of the Hanbalî school, Taqî al-Dîn Ahmad ibn Taymiyya (d. 1328). In 1306 Ibn Taymiyya was accused of anthropomorphism and sentenced to imprisonment on the ground that he taught that the descriptions of God in the Qur'ân are true in reality. The article examines Ibn Taymiyyas defence against the allegations of anthropomorphism and it demonstrates that Ibn Taymiyyas teaching was most of all an attempt to unite the dogma of God's transcendence with the teaching that the descriptions of God in the Qur'an are true.
\end{abstract}

Dorthe Bramsen

Ph.d.-stipendiat, cand.mag.

Carsten Niebuhr Instituttet

Københavns Universitet 